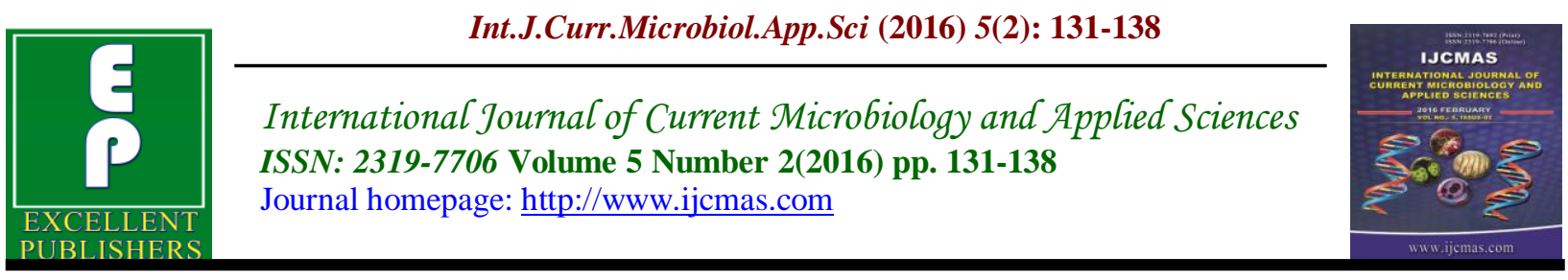

Original Research Article

doi: http://dx.doi.org/10.20546/ijcmas.2016.502.015

\title{
Prevalence of Nosema Infection of Honey Bees Colonies in Parts of Nasarawa and Plateau States, Nigeria
}

\author{
A. Dawet*, N. S. Jatau and D. P. Yakubu \\ University of Jos, Faculty of Natural Sciences, Department of Zoology, \\ Jos, Plateau State, Nigeria \\ *Corresponding author
}

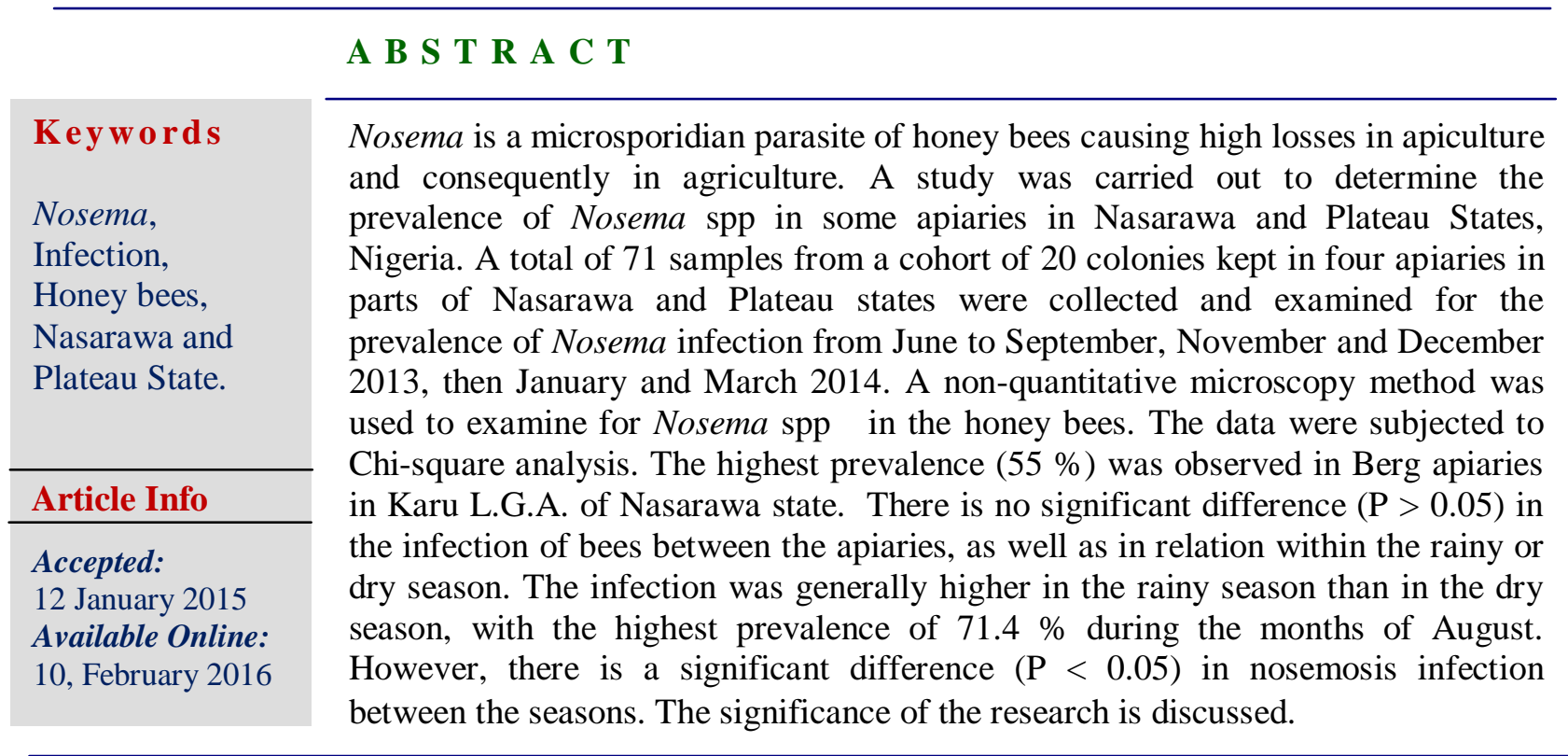

\section{Introduction}

Honey bees are the most important pollinators of many agricultural commodities which depend on insect pollination. On a global scale honey bees provide approximately $90 \%$ of commercial pollination in agricultural and hence honey bees health is of crucial importance not only for apiculture but also for agriculture and human food security (Klee et al., 2007). Unfortunately, today's beekeepers face significant hurdles to maintain healthy colonies that are capable of crop pollination because of dramatic honey bee colony mortalities in many regions of the world.

A great deal of attention has focused on these mortalities because humanity's reliance on pollinator-dependent crops has increased significantly in the last half century (Aizen and Harder, 2009). Honey bee mortality is believed to result from multiple stressors acting alone or in combination, including nutritional deficiencies, management issues, agro- 
chemicals, and especially introduced parasites (Williams et al., 2010).

$N$. ceranae is an important pathogen of honeybee colonies (Higes et al., 2013). Two microsporidian species have been found to be pathogenic for the western honey bee Apis mellifera, Nosema apis and Nosema ceranae (Fries et al., 2006) while Nosema apis infection is restricted to the mid gut epithelium of adult bees. Nosema ceranae was shown to also infect other tissues (Gisder et al., 2010). Recent studies suggest that Nosema ceranae might be more virulent than Nosema apis to both individual bees (Higes et al., 2007) and bee colonist (Higes et al., 2008). Nosema was detected in 528 (44\%) of the New York and $300(29 \%)$ of the South Dakota sampled apiaries. Comparative rates of $N$. ceranae and $N$. apis infection using molecular diagnostics on managed honey bee colonies from New York and South Dakota showed that $N$. ceranae was more prevalence than $N$. apis with $96.8 \%$ and $0.8 \%$ respectively in New York While out of the 122 (42\%) PCRpositive samples for South Dakota samples, all were N. ceranae (Szalanski et al., 2013). In a study to investigate and determine the presence of $N$. ceranae, its prevalence and distribution in all 21 districts of Croatia, Gajger et al., (2010) reported that $N$. ceranae was the only nosema species found to infect honeybees from our widespread geographic collection in Croatia. Not only does $N$. ceranae causes a clear pathology on honeybees at both the individual and colony levels, but it also has significant effects on the production of honeybee products (Higes et al., 2013). However, virulence and assertiveness of Nosema ceranae are obviously influenced by climate (Fries, 2010). Both species cause chronic disease that can shorten the adult lifespan and impact hive health and productivity and when infections reach high levels in apiaries, honey production and pollination services can be severely impacted (Bailey and Bail, 1991). Most other Nosema species, including the bumble bee pathogen, Nosema bombi, develop in most body tissues causing systemic infections rather than being restricted to one tissue. Many Nosema species infect the ovaries of reproductive female hosts and are transmitted from the infected females to their offspring (Becnel and Andreadis, 1999) but though Nosema apis infection in honey bee queens may affect the development of eggs and even stop reproduction ( Liu, 1992). The pathogen is not transmitted through the eggs to the offspring (Webster et al., 2008). The need for research in this field has become urgent. In particular, since the effects of this new parasite suggested a more severe impact on colony health compared to infections by Nosema apis (Higes et al., 2008). Therefore, this study aimed at determining the prevalence of Nosema spp in colonies of some apiaries in Jos North and Bassa LGA, Plataeu state and Auta balefi Karu L.G.A. Nasarawa state.

\section{Materials and Methods}

\section{Study Area}

The study areas include Jos wild Life Park apiaries in Jos-south L.G.A., Federal college of forestry Jos apiary in Jos-north L.G.A. and Gana apiary in Bassa L.G.A. of Plateau state. Berge honey Auta balefi apiaries Karu L.G.A. of Nasarawa state. The vegetation type is savannah with most of the areas covered with Short grasses and shrubs. The average daily temperature is between $18^{\circ} \mathrm{C}$ and $22^{\circ} \mathrm{C}$. There are two seasons, the rainy season (April to October) and the dry season (November to March). The dry season is characterized by cool dry dusty harmatan wind which blows south from the Sahara. At the height of hamatan in December and January, the temperature rises again, 
attaining a maximum of $31^{\circ} \mathrm{C}$ between February and April. The mean annual rainfall is recorded during the wet season months of July and August.

\section{Collection of Samples}

Four apiaries managed by hobbyist beekeepers in Nasarawa and Plateau States were monitored for Nosema infection in June to September, November and December 2013, January, and March 2014. A total of 71 samples from honey bee colonies kept in four apiaries were collected. Thirty to fifty bees were collected during each sampling from; under the lid, outside the cluster or from the hive entrance just before or after flight. The bees were kept in plastic containers with holes and either brought directly alive to be analysed freshly in the laboratory or stored in $70 \%$ ethanol and examined within three days.

\section{Microscopic Examination of Samples}

This was carried out with slide modification according to the methods describe by Lotfi et al., (2009); Gajger et al., (2010). Thirty adult bees were randomly selected from each sample and suspensions were created by adding $10 \mathrm{ml}$ distilled water to the abdomens of bees from a single colony, which was crushed using mortar and pestle. A drop from each sample was microscopically examined at $400 \times$ magnification for the presence of Nosema sp. spores.

\section{Statistical Analysis}

Data obtained were subjected to Chi square analysis using SPSS. Values with $\mathrm{P}<0.05$ were considered significant.

\section{Results and Discussion}

Of the 71 samples were examined, 25 samples $(35.21 \%)$ were positive for nosemosis infection (Table 1). In the Berg apiaries Karu L.G.A., Nasarawa State, 11 colonies $(55 \%)$ out of the 20 samples examined, were found to be infected. There was no visible signs of infection from samples of honey bees' colonies in Gana apiary in Bassa L.G.A. However, those from Jos Wild Life Park in Jos-south L.G.A. and College of forestry in Jos North L.G.A. Plateau State showed that 10 (34.48\%) and $4(25 \%)$ samples respectively were positive for Nosema. There was no significant difference $(\mathrm{P}>0.05)$ in the prevalence of Nosema spp in honey bee between the different apiaries.

The proportion of sample positive for Nosema spp in the cohort monitored was generally higher in the rainy season compared with the prevalence recorded during the dry season. In the rainy season, the highest prevalence $(71.43 \%)$ was recorded in August 2013 (Table 2). The dry season had lowest prevalence $(10 \%)$ in the month of January 2014 (Table 3). The prevalence according to season showed that $47.22 \%$ of the samples examined were positive for nosemosis infection during the rainy season, while $22.86 \%$ were found to be positive for nosemosis infection during the dry season (Table 4). Statistical analysis showed that there was a significant difference $(\mathrm{P}<0.05)$ in infection of nosemosis in relation to the seasons.

The high prevalence of Nosema infection of the honey bees during the rainy season than in the dry reported in this study is in accord with Akinwande et al., (2013) also reported high prevalence of Nosema infection in Lagos, Ogun and Osun States, in the southwestern parts of Nigeria during the rainy season than in the dry season. The northcentral regions of Nigeria are characterized by tropical climate and moderate humidity. 
Int.J.Curr.Microbiol.App.Sci (2016) 5(2): 131-138

Table.1 Prevalence of Nosema Spores in Common Samples from Some Apiaries in Nassarawa and Plateau States

\begin{tabular}{|c|c|c|c|c|}
\hline $\begin{array}{l}\text { Names of } \\
\text { Apiaries }\end{array}$ & & $\begin{array}{l}\text { Number } \\
\text { examined }\end{array}$ & $\begin{array}{r}\text { Number } \\
\text { Positive }\end{array}$ & $\begin{array}{l}\% \\
\text { Positive }\end{array}$ \\
\hline $\begin{array}{l}\text { Wildlife park. } \\
\text { Jos-south L.G.A. }\end{array}$ & & 29 & 10 & 34.48 \\
\hline $\begin{array}{l}\text { Gana apiary. } \\
\text { L.G.A. }\end{array}$ & Bassa & 6 & 0 & 00 \\
\hline $\begin{array}{l}\text { College of } \\
\text { Forestry Jos. } \\
\text { Jos-north L.G.A. }\end{array}$ & & 16 & 4 & 25 \\
\hline $\begin{array}{l}\text { Berg apiary. } \\
\text { Karu L.G.A. }\end{array}$ & & 20 & 11 & 55 \\
\hline TOTAL & & 71 & 25 & 35.21 \\
\hline
\end{tabular}

Table.2 Prevalence of Nosema Infection in Different Colonies of Honey Bees during the Rainy Season

\begin{tabular}{lccc}
\hline Months & $\begin{array}{l}\text { Number } \\
\text { examined }\end{array}$ & $\begin{array}{l}\text { Number } \\
\text { Positive }\end{array}$ & $\begin{array}{c}\text { \% } \\
\text { Positive }\end{array}$ \\
\hline June 2013 & 11 & 5 & 45.45 \\
July 2013 & 10 & 5 & 50 \\
August 2013 & 7 & 5 & 71.43 \\
September 2013 & 8 & 2 & 25.0 \\
TOTAL & 36 & 17 & 47.22 \\
\hline
\end{tabular}


Int.J.Curr.Microbiol.App.Sci (2016) 5(2): 131-138

Table.3 Prevalence of Nosema Infection in Different Colonies of Honey Bees during the Dry Season

\begin{tabular}{lccc}
\hline Months & Number examined & $\begin{array}{c}\text { Number } \\
\text { Positive }\end{array}$ & $\begin{array}{c}\% \\
\text { Positive }\end{array}$ \\
\hline November 2013 & 11 & 2 & 18.18 \\
December 2013 & 9 & 2 & 22.22 \\
January 2014 & 10 & 1 & 10 \\
March 2014 & 5 & 3 & 60 \\
TOTAL & 35 & 8 & 22.86 \\
\hline
\end{tabular}

Table.4 Prevalence of Nosema Infection in Honey Bees in Relation to the Seasons

\begin{tabular}{llcc}
\hline Seasons & $\begin{array}{l}\text { Number } \\
\text { examined }\end{array}$ & $\begin{array}{c}\text { Number } \\
\text { Positive }\end{array}$ & $\begin{array}{c}\% \\
\text { Positive }\end{array}$ \\
\hline Wet & 36 & 17 & 47.22 \\
Dry & 35 & 8 & 22.86 \\
TOTAL & 71 & 25 & 35.21 \\
\hline
\end{tabular}


This however brings about suitable conditions for the abundant occurrence of Nosema in apiaries. The infection of the honey bee colonies was of its utmost level in the spring (59.5\%), however the amount was considered to be low in the summer (3.33 $\%$ ) and no infection was observed during the fall (autumn) (Lotfi et al., 2009). The differences in prevalence in months reported in this study is contrary with MartinHarnandez et al., (2007) who report the absence of differences in the number of positive samples between months, showing evident lack of seasonality, and indicating a change in the clinical and epidemiological patterns of nosema disease. This variation could probably be due differences in environmental, climatic and management conditions.

Higes et al., (2013) reported that environmental conditions also strongly influence many parasitic relationships and, regardless of the effects of altitude, flora and colony management, in warm countries like Spain the influence of temperature on the consequences of $N$. ceranae has been observed. The fact is that $N$. ceranae is highly prevalent in warmer areas and its presence in the colony is very high. The absence of Nosema infection in Gana apiary could probably be due to good management system and fewer number of bees in that farm since all other apiaries were established in 2005 except that of Gana apiary which was established in 2013, and it had few numbers of bees compared with others. This inter colony variation in nosemosis could also be seen within bees in the same colony. Mulholland et al., (2012) reported considerable intra-colony variation in infection intensity among individual workers with a higher percentage of low-level infections detected by PCR than by spore counting. Colonies generally had the highest percentage of infected bees in early summer
(June) and the lowest levels in the fall (September).

From this study, it is obvious that Nosema infection occurred in colonies of in honey bees in some apiaries in Nasarawa and Plateau States. It therefore confirms that the disease has presumably been transferred from its original host Apis ceranae to Apis mellifera (Klee, et al., 2007). Although no Clinical signs of the disease were seen in the honey bees. This infection could probably be due to consumption of little amount of spores while they forage about. Similarly, mild subclinical infection could be achieved by inducing infected bees to feed on more protein rich materials rather than carbohydrate (Fries, 1993).

The present data raised a strong need for epidemiological and pathogenic studies to identify this emerging parasite. Higes et al., (2006) suggested that Nosema ceranae is a serious threat to the global bee keeping industry and natural biodiversity. The problem faced in the control of nosemosis caused by this parasite is in their asymptomatic duration (Martin-Harnandez, 2007). Bee keepers devote insufficient attention or often neglect nosemosis, because of its lack of symptoms. Currently, bee keepers in other parts of the world are using fumagillin, which is effective against Nosema apis infections. Fumagillin's impact on Nosema ceranae is still under evaluation (William et al., 2008). Bee keepers should employ prophylactic practices such as keeping colonies in sunny locations so as to reduce monitor Nosema levels. Colonies could receive good nutrition by planting of flowering tree crops that are rich in protein. Awareness should be created particularly to apiculturists and people who venture in apiculture on the identification and control of nosemosis. 


\section{References}

Aizen, M.A., Harder, L.D., (2009). The global stock of domesticated honey bees is growing slower than agricultural demand for pollination. Current Biology, 19: 915-918.

Akinwande, K. L., Badejo, M.A. and Ogbogu, S.S. (2013). Challenges associated with the honey bee (Apis mellifera adansonii) colonies establishment in south western Nigeria. African Journal of Food Agriculture Nutrition and Development. 13(2): 7467-7484.

Bailey, L. and Ball, B. V., (1991). Honey bee pathology. Academic press, London, New York, pp.193.

Becnel, J. J. and Andreadis, T. G. (1999). Microsporidia in insects. In:Wittner, M. and Weiss, L.M. Eds. The Microsporidia and microsporidiosis. American society for microbiology presses Washington, D. C. pp: 447501.

Fries, (1993). Nosema apis -a parasite in the honey bee colony. Bee World, 74 (1): 5-19.

Fries, I. (2010). Nosema ceranae in European honey bee (Apis mellifera). Journal of Invertebrate Pathology, 103: 573-153.

Fries, I., Martin, Meana, A., Garcia Pallencia, P., and Higes, M. (2006). Natural infections of $N$. ceranae in European honey bees. Journal of Apicultural Research, 45(4): 230- 233.

Gajger, T., Vugrek, O., Grilec, D. and Petrinec, Z. (2010). Prevalence and distribution of Nosema ceranae in Croatian honeybee colonies. Veterinarni Medicina, 55(9): 457462

Gisder, S., Hedtke, K., Mockel, K., Mockel, N., Frielitz, M.C., Linde, A. and Genersch E. (2010). Five-year cohort study of Nosema spp. in Germany. "Does climate shape virulence and assertiveness of Nosema ceranae? Applied Environmental Microbiology, 76 (9):3032- 3038.

Higes, M. R., Martin- Hernandez, R., Botias, C., Bailon, E.G., Gonzales -Porto, A .V., Barrios, L., Delnozal, M. J., Barnal J. L., Jimanez, J. J. , Palencia, P. G. and Meana, A. (2008). How natural infection by Nosema ceranae causes honey bee collapse. Environmental Microbiology, 10 (10): 2659-2669

Higes, M., García-Palencia, P., MartínHernández, R., Meana, A., (2007). Experimental infection of Apis mellifera honeybees with Nosema ceranae (Microsporidia), Journal of Invertebrate Pathology, 94: 211-217

Higes, M., Meana, A., Bartolomé, C., Botías, C. and Martín-Hernández, R. (2013). Nosema ceranae (Microsporidia), a controversial $21^{\text {st }}$ century honey bee pathogen. Environmental Microbiology Reports, 5(1): 17-29.

Klee, J., Besana, A.M., Genersch, E., Gisder, S., Nanetti, A., Tam, D.Q., Chinh, T.X., Puerta, F., Ruz, J.M., Kryger, P., Message, D., Hatjina, F., Korpela, S., Fries, I. and Paxton, R.J., (2007). Widespread dispersal of the microsporidian Nosema ceranae, an emergent pathogen of the western honey bee, Apis mellifera. Journal of Invertebrate Pathology, 96: 1-10.

Liu T.P., (1992). Oocytes degeneration in the queen honey bee after infestation by Nosema apis. Tissue Cell, 24: 131-138.

Lotfi, A., Jamshidi,R., Shahryar, H. A. and Yousefkhani, M. (2009). The Prevalence of Nosemosis in Honey Bee Colonies in Arasbaran Region (Northwestern Iran). American- 
Eurasian Journal of Agriculture \& Environmental Sciences, 5 (2): 255257.

Martin-Hernandez, R., Meana, A., Prieto, L., Salvador A.M., Garrido-Bailon E., Higes M. (2007) Outcome of colonization of Apis mellifera by Nosema ceranae, Applied Environmental Microbiology, 73: 6331-6338.

Mulholland, G. E., Traver, B. E., Johnson, N. G. and Fell, R. D. (2012). Individual Variability of Nosema ceranae Infections in Apis mellifera Colonies. Insects, 3: 1143- 1155.

Szalanski, A. L., Whitaker, J., Tripodi, A. D, and Cappy, P. (2013). Prevalence of Nosema from managed honey bee colonies in South Dakota and New York. Journal of Agricultural and Urban Entomology, 29(1):99-104.
Webster, T.C., Pomper, K. W., Hunt, G., Thacker, E. M. and Jones, S.C. (2008). Nosema apis infection in worker and queen Apis mellifera queens. Journal of Apicultural Research and Bee World, 47: 53-57.

Williams, G. A., Shafer, D., Shutter, R., Rogers, and Stewart, D. (2008). First detection of Nosema ceranae, a microsporidian parasite of European honey bees (Apis mellifera) in Canada and Central U.S.A. Journal Invertebrate Pathology, 96: 189-192.

Williams, G.R., Head, K., BurgherMacLellan, K.L., Rogers, R.E.L., Shutler, D., (2010). Parasitic mites and microsporidians in managed western honey bee colonies on the island of Newfoundland, Canada. The Canadian Entomologist, 142: 584-588.

\section{How to cite this article:}

Dawet, A., N. S. Jatau and Yakubu, D. P. 2016. Prevalence of Nosema Infection of Honey Bees Colonies in Parts of Nasarawa and Plateau States, Nigeria. Int.J.Curr.Microbiol.App.Sci. 5(2): 131-138. doi: http://dx.doi.org/10.20546/ijcmas.2016.502.015 